\title{
LAJU PINDAH PANAS SECARA KONDUKSI DAN PENGUAPAN AIR SELAMA PROSES PENGERINGAN GABAH MENGGUNAKAN CABINET DRYER
}

\section{HEAT TRANSFER RATE IN CONDUCTION AND EVAPORATION OF WATER DURING THE DRYING PROCESS OF GRAIN USING CABINET DRYER}

\author{
Sasmita1), Jamaluddin²), Husain Syam ${ }^{3)}$. \\ ${ }^{1}$ Alumni Program Studi Pendidikan Teknologi Pertanian \\ ${ }^{2}$ dan ${ }^{3}$ Dosen PTP FT UNM \\ sasmita.ptp14@gmail.com
}

\begin{abstract}
ABSTRAK
Tujuan dari penelitian ini adalah untuk mengetahui mekanisme perpindahan panas dan penguapan air pada gabah selama proses pengeringan menggunakan udara panas sebagai media penghantar panas. Penelitian ini berbentuk eksperimen yang terdiri dari dua variabel yaitu variabel $A$ adalah suhu dengan 3 taraf50, $60^{\circ}$ dan $70^{\circ} \mathrm{C}$ dan variabel $B$ adalah lama pengeringan dengan 3 taraf160, 170, dan 180 menit. Sampel penelitian adalah gabah basah dengan kadar air awal 20,51\% dikeringkan menggunakan alat pengering berbentuk lemari (cabinet dryer). Untuk mengetahui perubahan suhu yang terjadi maka proses pengeringan dilakukan pengukuran suhu lingkungan/udara dan suhu gabah menggunakan termokopel. Sebelum dan sesudah pengeringan dilakukan pengukuran kadar air untuk mengetahui perubahan kadar air gabah dari setiap perlakuan yang digunakan. Hasil penelitian menunjukkan bahwa semakin tinggi suhu dan semakin lama pengeringan digunakan maka laju perpindahan panas semakin tinggi, maka penguapan air semakin besar, sehingga menyebabkan kadar air gabah menurun.
\end{abstract}

Kata Kunci :Pengeringan, Perpindahan panas, Penguapan air, Cabinet Dryer, Gabah.

\begin{abstract}
The purpose of this research is to know the mechanism of heat transfer and water evaporation grain water during drying process using hot air as heat conducting media. This experiment is an experiment consisting of two variables, namely variable $A$ is temperature with 3 level $50^{\circ}, 60^{\circ}$ and $70^{\circ} \mathrm{C}$ and variable $B$ is drying time with 3 level 160, 170, and 180 minutes. The sample was wet grain with initial moisture content of $20.51 \%$ dried using a cabinet dryer. To determine the temperature changes that occur then the drying process is done by measuring the temperature of the environment / air and grain temperature using thermocouple. Before and after drying the water content is measured to determine the change of grain water level of each treatment used. The results showed that the higher temperature and the longer drying is used the higher heat transfer rate, the greater the evaporation of water, causing the grain water content to decrease.
\end{abstract}

Keywords: Drying, Heat transfer, Evaporation of water, Cabinet Dryer, Grain. 


\section{PENDAHULUAN}

Padi/gabah (oryza sativa (I)) merupakan salah satu bahan makanan yang paling penting didunia. Padi merupakan penghasil makanan berbasis biji-bijian terbesar kedua di dunia (Charoenchaisri, et al, 2010). Di Indonesia sendiri, padi telah menjadi komoditas strategis yang dapat mempengaruhi berbagai aspek kehidupan. Hal ini dikarenakan padi merupakan sumber makanan utama sebagian besar penduduk di pedesaan. Semakin besar jumlah penduduk, maka akan semakin besar kebutuhan akan pangan, terutama beras. Sehingga, dibutuhkan peningkatan produksi beras nasional (Aryunis, dkk, 2008; Bintoro, dkk, 2008).

Selama ini masyarakat di Indonesia telah terbiasa melakukan pengeringan gabah dengan cara konvensional, yaitu dengan cara di jemur langsung dibawah sinar matahari. Penjemuran bisa menghabiskan waktu 3-7 hari dan sangat tergantung oleh besarnya penyinaran matahari (Atthajariyakul and Leephakpreeda, 2006). Selain itu, kelemahan dari pengeringan dengan cara konvensional ini adalah produk gabah hasil pengeringan tidak seragam, lebih mudah terkontaminasi oleh kotoran atau debu sehingga dapat mengurangi mutu akhir produk yang dikeringkan, dan membutuhkan area serta biaya operasional yang besar. Oleh karena itu, diperlukan alat pengering mekanis. Alat pengering mekanis digunakan selain dapat mempercepat proses pengeringan juga dapat mengurangi bercampurnya debu ataupun kotoran lainnya serta dapat lebih terkendali.

Pengeringan gabah basah dapat dilakukan dengan menggunakan alat pengering buatan, salah satunya adalah Cabinet dryer. Cabinet dryer merupakan alat pengering mekanis yang memanfaatkan penguapan energi panas. Proses pengeringan merupakan proses perpindahan sejumlah massa uap air secara simultan, dengan membutuhkan energi untuk menguapkan kandungan air yang dipindahkan dari permukaan bahan ke media pengering. Proses berpindahnya sejumlah massa uap air karena adanya perbedaan konsentrasi uap air antara suatu bahan dengan lingkungannya. Selama proses pengeringan gabah basah akan terjadi proses laju pindah panas dan penguapan air akan terjadi beberapa perubahan pada produk pangan seperti perubahan kadar air, volume, dan perubahan warna. Semakin tinggi suhu pengering maka semakin banyak air yang menguap dan menyebabkan kadar air gabah basah menurun. Berdasarkan uraian diatas maka penulis terdorong untuk melakukan penelitian yang berjudul laju pindah panas dan penguapan air selama proses pengeringan gabah menggunakan Cabinet dryer.

\section{TUJUAN PENELITIAN}

Penelitian ini bertujuan untuk mengetahui laju pindah panas pada gabah selama proses pengeringan menggunakan mesin Cabinet dryer dan untuk mengetahui penguapan air pada 
gabah selama proses pengeringan menggunakan mesin Cabinet dryer.

\section{METODE PENELITIAN}

Jenis penelitian ini merupakan penelitian eksperimen yang terdiri atas 2 variabel. Variabel $A$ adalah suhu dengan 3 taraf variabel $\left(50^{\circ} \mathrm{C}, 60^{\circ} \mathrm{C}\right.$ dan $\left.70^{\circ} \mathrm{C}\right)$ dan variabel $B$ adalah lama pengeringan dengan 3 taraf variabel (160 menit, 170 menit dan 180 menit). Dengan demikian banyaknya perlakuan yang dicobakan sebanyak 9 dimana masing-masing dilakukan pengulangan 3 kali dengan memperoleh sampel 27. Pada penelitian ini akan dilakukan pengeringan gabah dengan menggunakan alat pengering Cabinet dryer dengan sumber pemanas berasal dari kompor gas yang berfungsi untuk memanaskan plat kemudian panas dialirkan kepermukaan gabah dengan menggunakan blower. Gabah yang digunakan pada penelitian ini merupakan gabah basah yang baru selesai panen. Selama proses pengeringan akan diukur suhu gabah dengan menggunakan alat termokopel dan direkam dengan data logger dan dilakukan pengukuran suhu ruang gabah pada pengering Cabinet dryer.

Penelitian ini dilakukan di Laboraturium Pendidikan Teknologi Pertanian Fakultas Teknik Universitas Negeri Makassar. Dan Waktu penelitian ini dilaksanakan pada Bulan Januari 2017 di Laboraturium Pendidikan Teknologi Pertanian Fakultas Teknik Universitas Negeri Makassar.

Peralatan dan bahan yang digunakan dalam penelitian ini adalah Cabinet dryer, timbangan, toples, stopwatch, oven, baskom, plastik klip, plastik food, thermocouple, desikator, aluminium foil, gunting, tali rapia, sarung tangan, cawan, penjepit, talenan, lakban, perekam data, komputer dan gabah basah.

Data dikumpulkan dilakukan dengan cara Laju pindah panas yang dihitung mulai dari pindah panas dari plat rak pengering ke permukaan gabah, dan dari permukaan gabah ke bagian dalam gabah dengan menggunakan persamaan laju pindah panas secara konduksi sebagai beriku :

$$
\mathrm{Q}=k \quad \frac{a}{a}
$$

Dan penelitian ini juga lakukan pengukuran kadar air digunakan untuk mengukur seberapa banyak air yang menguap dari dalam gabah untuk mengetahui tersebut. Kadar air dapat dihitung dengan menggunakan persamaan berikut ini :

$$
\text { Kadar air } \%=\frac{B-C}{B-A} X 100 \%
$$

\section{HASIL DAN PEMBAHASAN}

Penelitian ini dilakukan dengan mengeringkan gabah basah menggunakan mesin cabinet dryer. Pengeringan dilakukan dengan perlakuan suhu dan lama pengeringan yang berbeda. Suhu pengeringan terdiri dari 50,60 , dan $70^{\circ} \mathrm{C}$, sedangkan lama pengeringan terdiri dari 160,170 , dan 180 menit. Pengeringan gabah sebelum dan setelah pengeringan untuk setiap perlakuan dilakukan pengukuran kadar air dan laju pindah panas. Pengukuran kadar air sebelum dan setelah 
pengeringan bertujuan untuk mengetahui perubahan kadar air yang dihasilkan dari setiap perlakuan suhu dan lama pengeringan sehingga dapat diketahui pula laju pindah panas secara konduksi selama pengeringan. Laju pindah panas dilakukan setiap 10 menit pengeringan pada gabah, pengeringan ini dapat menurunkan kadar air seperti hasil yang terdapat di Gambar 4.1, semakin cepat laju perpindahan panas maka semakin besar pula air yang teruap didalam gabah.

Fenomena laju pindah panas menurunkan kadar air pada setiap waktu dapat dijelaskan dengan dasar pengeringan. Pada proses awal pengeringan, suhu panas akan naik dengan cepat dikarenakan adanya mekanisme perpindahan panas dan terjadilah penguapan kadar air pada permukaan gabah. Teruapnya air pada gabah tersebut dapat diketahui berapa banyak air yang teruapkan pada setiap waktu yang digunakan. Bertambahnya waktu pengeringan dari gabah akan mendekati kadar air konstan karena proses yang berperan adalah uap air dari dalam menuju keluar bahan, dimana proses ini memanfaatkan panas konduksi dari bahan itu sendiri. Oleh karena itu, waktu gabah yang terjadi semakin lama semakin kecil dan cenderung menuju konstan.

\section{Penguapan Kadar Air}

Penelitian ini dilakukan perhitungan kadar air gabah sebelum dan setelah pengeringan. Hasil perhitungan kadar air gabah menunjukkan bahwa setiap perlakuan suhu dan lama pengeringan yang diberikan akan menghasilkan kadar air gabah yang berbeda-beda pada setiap perlakuan. Hasil perhitungan kadar air gabah dengan menggunakan suhu dan lama pengeringan yang berbeda-beda dapat dilihat pada Gambar 1.

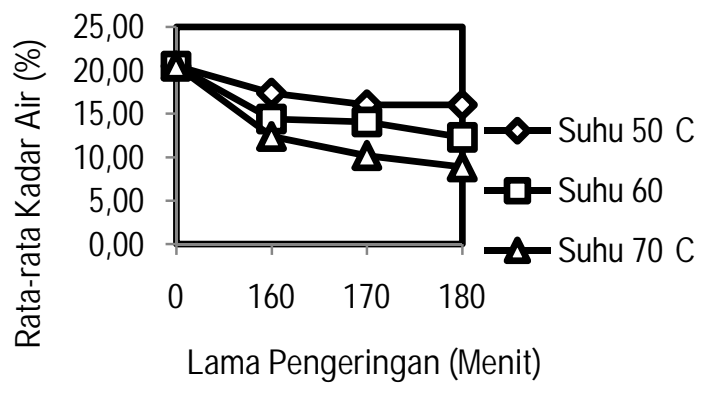

Gambar 1

Hasil perhitungan kadar air selama pengeringan menggunakan cabinet dryer dengan variasi waktu dan suhu yang berbeda-beda

Berdasarkan hasil analisis
perhitungan kadar air gabah menunjukkan bahwa perlakuan suhu dan lama pengeringan yang berbeda menghasilkan kadar air yang berbeda pula. Pada gambar 1 dengan berbagai variabel waktu 160, 170, dan 180 menit dengan perlakuan suhu $50^{\circ}$ memperoleh kadar yang tertinggi dengan rata-rata $17,41 \%$, sedangkan kadar air yang terendah adalah dari perlakuan suhu $70^{\circ}$ dan lama pengeringan 180 menit dengan diperoleh rata-rata 8,89\%. Berdasarkan hasil yang diperoleh dari perubahan kadar air, maka dapat diketahui bahwa dengan menggunakan suhu yang rendah dan lama pengeringan yang cepat akan menghasilkan perubahan kadar air yang rendah pula, sedangkan dengan menggunakan suhu yang tinggi dan lama 
pengeringan yang lama akan menghasilkan perubahan kadar air yang tinggi pula. Dari hasil yang diperoleh dapat disimpulkan bahwa diduga faktor yang mempengaruhi kadar air pada gabah yang berbeda-beda adalah faktor suhu dan lama pengeringan.

Berdasarkan hasil perhitungan kadar air dapat diketahui bahwa semakin tinggi suhu dan semakin lama waktu pengeringan akan menyebabkan penguapan air pada penurunan kadar air semakin besar, hal ini dikarenakan suhu yang tinggi akan menyebabkan cepatnya panas merambat ke permukaan bahan yang dikeringkan sehingga akan menguapkan air di dalam bahan. Hal ini didukung dengan pernyataan Irawan (2011) dalam Hidayati dkk., (2013) bahwa perbedaan suhu antara media pemanas dan bahan yang makin besar menyebabkan makin cepatnya perpindahan panas kedalam bahan dan makin cepat pula perpindahan uap air dari bahan ke lingkungan. Selain itu Mujumdar (2004) dalam Ivan dkk., (2013) juga mengemukakan bahwa semakin besar beda suhu antara pemanas dengan bahan, maka proses transfer panas ke dalam bahan juga akan semakin cepat. Oleh karena itu, semakin tinggi suhu udara pengering, maka semakin cepat proses pengeringannya. Hal ini sejalan dengan hasil penelitian Martunis (2012) yang melaporkan bahwa dengan perlakuan lama pengeringan, semakin lama pengeringan berlangsung (7 jam) maka penguapan air di dalam bahan semakin cepat terjadi sehingga kadar air nya pun semakin berkurang.

Pada awal proses pengeringan penguapan kadar air melaju lebih cepat hal ini disebabkan karena banyaknya kandungan air pada bahan, sehingga penguapan air terlebih dahulu terjadi pada permukaan bahan. Air bebas merupakan air yang mudah menguap dari bahan makanan dikarenakan ikatan hidrogen yang lemah dalam air bebas (Winarno, 2002). Selanjutnya penurunan laju penguapan air hal ini disebabkan karena sebagian besar air di permukaan bahan telah menguap sehingga penguapan air berlanjut ke bagian dalam bahan dan cenderung konstan, hal ini disebabkan penguapan air dari bahan telah menurun seiring dengan penurunan kadar air selama proses pengeringan sehingga jumlah air bebas makin lama semakin berkurang dan permukaan partikel bahan tidak lagi ditutupi oleh lapisan air, sehingga laju penguapan air pada perlakuan ini mengalami penurunan dan cenderung konstan.

\section{Laju Perpindahan Panas Secara Konduksi}

Perhitungan laju pindah panas dalam penelitian ini yaitu laju pindah panas pada gabah dengan menggunakan pendekatan persamaan dapat dilihat 1. Hasil perhitungan laju perpindahan panas selama proses pegeringan gabah dapat dilihat pada Gambar 4.2, 4.3 dan 4.4. 


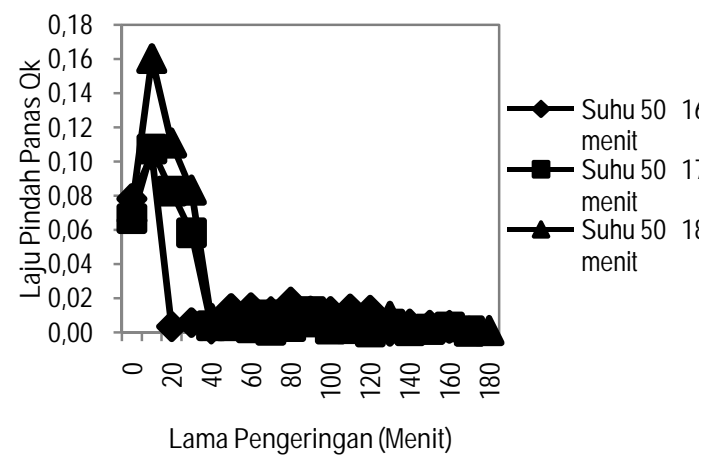

Gambar 2

Hasil perhitungan laju pindah panas

suhu $50^{\circ} \mathrm{C}$

Berdasarkan gambar 2 hasil perhitungan laju perpindahan panas pada gabah, bahwa perpindahan panas meningkat lebih cepat pada awal pengeringan. Hal ini disebabkan karena pada awal pengeringan air yang dapat teruapkan pada permukaan lebih banyak dan semakin menurun hingga akhir pengeringan, seiring dengan bertambahnya waktu maka suhu dari bahan menurun dan akan mendekati konstan karena proses yang berperan adalah uap air dari dalam menuju keluar bahan. Berdasarkan hasil perhitungan laju perpindahan panas yang terjadi selama proses pengeringan dapat disimpulkan bahwa suhu dan lama pengeringan akan berpengaruh terhadap laju perpindahan panas, semakin tinggi suhu udara pengering, maka proses pengeringan akan semakin cepat. Hal ini dikarenakan dengan peningkatan suhu udara pengering, maka semakin besar pula energi panas diberikan pada gabah yang dikeringkan sehingga dapat membawa air yang terkandung dalam gabah lebih banyak.

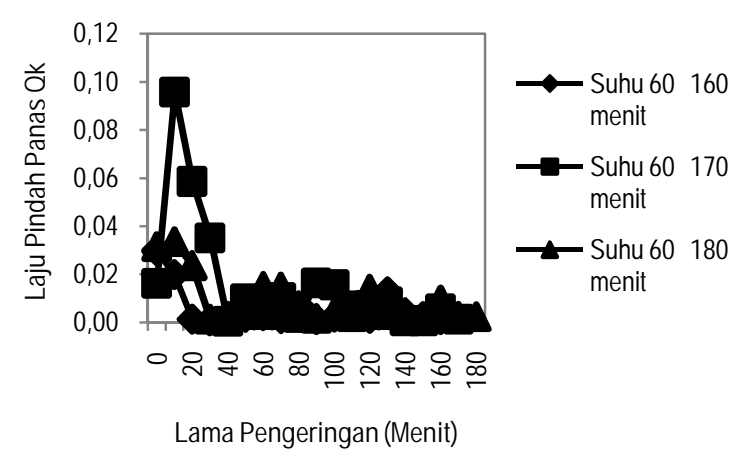

Gambar 3

Hasil perhitungan laju pindah panas suhu $60^{\circ} \mathrm{C}$

Berdasarkan gambar 3 hasil perhitungan laju perpindahan panas yang terjadi selama proses pengeringan dapat dilihat bahwa awal proses pengeringan mengalami perpindahan panas lebih cepat. Hal ini disebabkan bahwa air permukaan bahan lebih banyak teruapkan, seiring berjalannya waktu proses pengeringan mengalami penurunan kadar air dan mendekati konstan. Penguapan mula-mula terjadi pada air di permukaan, setelah air permukaan berkurang maka terjadi pengaliran air antar sel ke permukaan, karena proses keseimbangan kadar air di dalam gabah sendiri. Proses ini berjalan sampai keadaan air sel dan kadar air permukaan tertentu, selanjutnya dinding sel mengambang dan air dalam sel mengadakan keseimbangan dengan kadar air seluruhnya sehingga ada pengaliran air antara sel. Proses ini terjadi berulang kali sampai terjadi pemindahan air dari dalam gabah ke udara. 


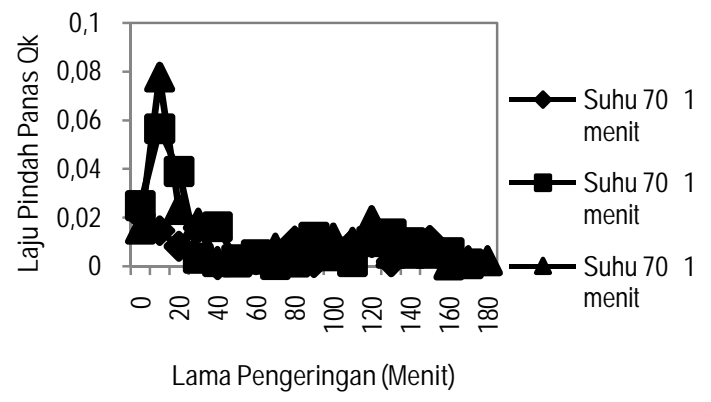

Gambar 4

Hasil perhitungan laju pindah panas suhu $70^{\circ} \mathrm{C}$

Berdasarkan gambar 4 hasil perhitungan laju perpindahan panas yang terjadi selama proses pengeringan dapat dilihat bahwa pada awal proses pengeringan mengalami perpindahan panas lebih cepat, hal ini disebakan oleh udara panas yang menyentuh bahan sehingga dipermukaan gabah cepat teruapkan, seiring berjalannya waktu proses perpindahan panas akan menurun dan mendekati konstan. Hal ini dikarenakan air dalam gabah mulai berkurang dapat disimpulkan bahwa suhu dan lama pengeringan akan berpengaruh terhadap laju perpindahan panas, semakin tinggi suhu udara pengering, maka proses pengeringan akan semakin cepat.

Berdasarkan gambar 2, 3, dan 4 menunjukkan bahwa Semakin tinggi suhu dan semakin lama pengeringan digunakan semakin cepat pula terjadi laju perpindahan panas. Dengan menggunakan suhu yang berbeda dengan waktu yang berbeda akan berpengaruh pula hasil yang didapatkan. Hal ini dikarenakan pada setiap peletakan rak-rak digunakan dapat perpengaruh disebabkan oleh udara yang diterima setiap per rak dan dapat juga berpengaruh pada luas permukaan yang digunakan setiap per rak. Hal ini didukung dengan pernyataan Mayani dkk.,(2012) dalam Cynthia dkk.,(2013) bahwa proses pengeringan dibutuhkan luas permukaan yang besar agar dapat mempercepat proses pengeringan karena semakin banyak luas permukaan yang mengalami kontak dengan udara panas. Selain itu sesuai dengan penelitian Jamaluddin dkk.,(2011) menjelaskan bahwa keluarnya secara perlahan-lahan se-bagian air bebas menyebabkan rongga menjadi mengecil dan secara bersamaan terbentuk lapisan keras di permukaan padatan. Fenomena tersebut dapat dijelaskan dengan mekanisme dasar pengeringan. Pada proses awal pengeringan, temperatur partikel akan naik dengan cepat dikarenakan adanya mekanisme perpindahan massa dan panas sehingga terjadi uap air kontinyu di permukaan. Seiring dengan bertambahnya waktu maka suhu dan pertikel akan mendekati konstan karena proses yang berperan adalah difusi uap air dari dalam menuju keluar bahan, dimana proses ini terjadi perpindahan panas konduksi dari bahan itu sendiri. Oleh karena itu, gradien suhu pertikel yang terjadi semakin lama semakin kecil dan cenderung menuju konstan irvan dkk, (2013).

\section{KESIMPULAN}

Berdasarkan hasil penelitian dapat disimpulkan yaitu sebagai berikut :

1. Semakin tinggi suhu dan semakin lama pengeringan digunakan maka 
laju perpindahan panas semakin cepat, sehingga berpengaruh terhadap terjadinya perubahan kadar air pada gabah atau menyebabkan kadar air menurun.

2. Semakin tinggi suhu maka penguapan air semakin meningkat yang menyebabkan semakin berkurangnya kadar air dalam gabah.

\section{SARAN}

Adapun saran yang dapat diberikan setelah melakukan penelitian ini yaitu untuk peneliti selanjutnya dapat meneliti perubahan karakteristik gabah yang terjadi selama proses menggunakan mesin cabinet dryer.

\section{DAFTAR PUSTAKA}

Aryunis, H., Muhammad, I., Tafzi, F., Esrita, W. Dan Ratna, Y., 2008, Peningkatan Produksi Padi Melalui Pemanfaatan Varietas Unggul Baru Hasil Litbang Iptek Nuklir di Desa Rambah Kecamatan Tanah Tumbuh Bungo, Jurnal Pangabdian pada Masyarakat, no. 46, hh. 39-40.

Athajariyakul, S and Leephakreeda, T.,(2006), "Fluidized Bed Paddy Drying in Optimal Conditions Via Adaptive Fuzzy Logic Control", Journal of Food Engineering., 75, 104-114, Bangkok.

Bintoro, N., Susanti, D.Y. dan Zuhrotul, H.A., 2008. Unjuk Kerja Mesin Penggiling Padi Tipe Single Pass,
Prosiding Seminar Nasional Teknik Pertanian. Universitas Gajah Mada, Yogjakarta.

Cynthia Anggi Maulina, Ahyadani Rosarrah, Muhammad Djaeni. 2013. Aplikasi Spray Dryer untuk Pengeringan Larutan Garam Amonium Perklorat Sebagai Bahan Propelan,vol.2, No.4, Jurusan Teknik Kimia. Fakultas Teknik. Universitas Diponegoro.

Irawan Anton, ST., MT. 2011. Modul Laboratorium Pengeringan. Jurusan Teknik Kimia. Fakultas Teknik. Universitas Sultan Ageng Tirtayasa.

Ivan Aditya Gunawan, Aulia Rahman Majid, Siswo Sumardiono. 2013. Pengeringan Gabah dengan Menggunakan Pengering Resirkulasi Kontinyu Tipe Konveyor Pneumatik. Jurusan Teknik Kimia. Fakultas Teknik, Universitas Diponegoro. Semarang

Jamaluddin, Suardy, Siswantor, dan Suriana Laga. 2011. Pengaruh Suhu dan Tekanan Vakum Terhadap Penguapan Air, Perubahan Volume dan Rasio Densitas Keripik Buah Selama dalam Penggorengan Vakum. Vol.12, No.2, Fakultas Teknik. Universitas Negeri Makassar.

Mayani, H, Violleni, prihadi. 2012. Metode Pengeringan Menggunakan Metode Spray 
Dryer (Continous Drying). Universitas Jendral Sudirman.

Martunis. 2012. Pengaruh Suhu dan Lama Pengeringan Terhadap Kuantitas dan Kualitas Pati Kentang Varietas Granola. jurusan Teknologi Hasil Pertanian. Fakultas Pertanian. Universitas Syiah Kuala. Darussalam. Benda Aceh-23111, Indonesia.

Mujumdar, arun S. 2004. Guid To Industri Drying Principle, Equitment and New Development. Iwsid: Mumbai, India.

Hidayati Noor, Utami Diah P., Ratnawati, Suherman, 2013. Penerapan Teknologi Fluidized Bed Dryer dengan Panambahan Zeolit 3a untuk Meningkatkan Efisiensi Pengeringan Gabah, Jurusan Teknik Kimia, Fakultas Teknik, Universitas Diponegoro.

Winarno, F. G. 2002. Kimia Pangan dan Gizi. Jakarta: Gramedia Pustaka Utama. 